\title{
Apyrase like proteins and epigenetic roles during initial germination of (Pisum sativum L.) seedlings
}

\author{
Mahmoud F.M. Moustafa ${ }^{1 *}$ Elsayed E.Hafez ${ }^{2}$ \\ Botany Department, Faculty of Science, South Valley University, Egypt ${ }^{1}$ \\ Mubarak City for scientific Research and Technology Applications, Alexandria, Egypt. ${ }^{2}$
}

Rec. 4 June, Accpt. 1 July 2010

\begin{abstract}
Apyrase is a CaM-binding proteins and it is playing an important roles in response to biotic and abiotic stresses during embryo development. The expression of different isotypes of $36 \mathrm{kDa}$ and $46 \mathrm{kDa}$ antigenic to apyrase in dry seeds, during imbibition, and initial germination were examined using 2D-gel and western blotting. Both of the two genes were highly expressed in dry seeds and imbibiation ones but they were completely disappeared during germination. Thirteen different isotypes for the $46 \mathrm{kDa}$ was observed with $\mathrm{p} I$ 5.3, 5.4, 5.6, 5.8, 6.0, 6.3, 6.6, 6.8, 7.4, 7.5, 7.55, 7.65 and 7.7 while in case of the 36 $\mathrm{kDa}$ only two isotypes were demonstrated with $\mathrm{p} I 7.3$ and 7.35 . Further studies were carried out on both of the embryo protein content and ATPase activity, the protein content was decreased by increasing the ATPas activity during the embryo development. In conclusion, both of the 46 and $36 \mathrm{kDa}$ proteins are two separate enzymes correlated to apyrase enzyme. In addition, the different isotypes of the both enzymes are kind of epigenetic effect which carried out by the highly developed cells to produce different forms of proteins. These proteins perform different function during the germination process. They suppress a default death pathway in plants.
\end{abstract}

Key words: Apyrase gene, seed imbibitions and germination and biological control.

\section{Introduction}

Many scientists postulated that apyrases hydrolyze nucleoside tri-and diphosphates and are highly active and most likely ubiquitous, because they have been found in all pro-and eukaryotic organisms (Plesner, 1995; Komoszynski and Wojtczak, 1996). The function of plant apyrases has been studied most intensively in legumes, namely Dolichos biflorus, wild soybean (Glycine soja), Medicago truncatula, and pea (Pisum sativum). In wild soybean and D. biflorus, two apyrases each were cloned, Db-apyrase1/Dbapyrase- 2 (Roberts et al., 1999) and Gs50/Gs52 (Day et al., 2000), both of them contain a predicted transmembrane domain at the $\mathrm{N}$ terminus. The physiological roles of plant apyrases have been studied using the pea NTPase (Hsieh et al., 1996) and the overexpression of this apyrase in Arabidopsis lines led to increased scavenging of extracellular phosphate (Thomas et al., 1999 as well as, a pea apyrase was found to co- purify with the cytoskeleton and was hypothesized to play a role in mRNA transport along the cytoskeleton (Shibata et al., 1999).

Seed dormancy is maintained by complex interactions between environmental and genetic factors that are little understood and several studies have shown that ethylene, gibberellic acid, brassinosteroids and abscisic acid (ABA) promote the germination of dormant seeds (Koornneef et al., 2002; Gubler et al., 2005). Biosynthesis and accumulation of storage proteins, lipids, and starch macromolecules have been investigated in relation to the cellular differentiation, which ultimately serve as nutrients for the postgerminative seedling (Jenner 1982; Slack and Browse 1984; Shotwell and Larkins 1989; Galili et al., 1993). Protein analysis provides a complementary approach to the study of plant embryo development; it allows proteins with essential functions during this critical stage of the plant life cycle to be identified.

\footnotetext{
* Corresponding author:

Dr. Mahmoud F.M. Moustafa

$\varangle$ hamdony@yahoo.com
} 
During imbibition, the cell will recover their activity. Then, during germination, the seed will swell in the presence of water up to the protrusion of root tips but the entire process of germination is not well understood at a molecular level (Bewley and Black 1994; Bewley 1997; Bewley et al., 1997). For instance, it is not known whether the newly synthesized or consumed products are essential for this intermediary phase of development, accumulated as storage for subsequent tissue development or are essential for breaking the seed dormancy.

ATP is a vital molecule used by living organisms as a universal source of energy required to drive the cogwheels of intracellular biochemical reactions necessary for growth and development. The major NTPase from rat liver nuclei appears to be a $46-\mathrm{kD}$ enzyme that represents the $\mathrm{N}$-terminal portion of lamins $\mathrm{A}$ and $\mathrm{C}$, two lamina proteins that apparently arise from the same gene by alternate splicing. Monoclonal antibody (MAb) $\mathrm{C} 2$, raised to human lamin $\mathrm{C}$, both immunoprecipitates the major $(47 \mathrm{kD})$ NTPase in pea nuclei and was determined by western blot (Tong et al., 1993). Chivasa et al., (2005) reported that the extracellular ATP is essential for maintaining plant cell viability and its removal by the cell-impairment traps glucose-hexokinase and apyrase triggered death in both cell cultures and whole plants. Additionally, that the death response was observed in Arabidopsis thaliana, maize (Zea mays), bean (Phaseolus vulgaris), and tobacco (Nicotiana tabacum). Meanwhile, the fumonisin B1 (FB1) treatment of Arabidopsis was triggered the depletion of extracellular ATP that preceded cell death and that exogenous ATP rescues Arabidopsis from FB1-induced death.

The main objectives of this study were to investigate the status of isotypes of $36 \mathrm{kDa}$ and 46 $\mathrm{kDa}$ in dormant seed, during imbibitions and initial germination. The effect of prolonged imbibitions upon germination of Alaska pea seeds was also studied. The obtained results will help in identifying proteins which express during the germination period and that already persistent in the dormant seeds. The roles of such protein in breaking the seed dormancy and the driven defense approach to the embryo until give the shoot and root systems were discussed.

\section{Materials and Methods}

\section{Plant materials and sample preparation}

Pea (Pisum sativum L. var. Alaska) seeds were imbibed in water for 60 hours; some of them were sown after 10 hours of imbibition in vermiculite to allow germination in the dark at $21-23{ }^{\circ} \mathrm{C}$. After 0 , $10,20,30,40,60$ hours of imbibition and 24 hours of germination, three grams of intact embryonic tissues, were dissected from the cotyledons, collected on ice, and ground with a mortar and pestle in 7 volumes of cytoskeleton stabilizing buffer (CSB) consisting of $5 \mathrm{mM}$ HEPES-KOH (pH 7.5), $10 \mathrm{mM} \mathrm{Mg}$ (OAc) 2, 2mM EGTA, and 1 $\mathrm{mM}$ PMSF with the addition of $0.5 \%$ PTE. The homogenate was filtered through two layers of Miracloth (Calbiochem) and the filtrate was used for further experiments.

\section{Imbibition and germination}

Pea (Pisum sativum L. var. Alaska) seeds were imbibed in water for 10, 20, 30, 40, 50, 60 hours. Then, 100 seeds were sown in vermiculite to allow germination in the dark at $21-23{ }^{\circ} \mathrm{C}$. The number of germinated seeds after every imbibitions time was estimated.

\section{Determination of protein content}

Protein content of embryonic axes of dry pea seeds after imbibition for 10, 20, 30, 40, 50 , and 60 hours or germination were determined using Bio-Rad protein Assay Kit (Bio-Rad Laboratories CA, USA) and BSA as a standard (Bradford 1976).

\section{Assay of total ATPase activity}

Embryonic axes of dry or imbibed pea seeds were collected, homogenized in CSB, and filtered through Miracloth. Aliquots $(1 \mu \mathrm{L})$ of tissue homogenate diluted to the appropriate concentration with CSB were added into $83.3 \mu \mathrm{L}$ of the assay mixture $(100 \mathrm{mM}$ Tricine- $\mathrm{NaOH}(\mathrm{pH}$ 7.5), $10 \mathrm{mM}$ substrate (nucleoside triphosphate), $10 \mathrm{mM} \mathrm{CaCl} 2$ ), and incubated at $25^{\circ} \mathrm{C}$ for $15 \mathrm{~min}$. The reactions were stopped by adding $16.7 \mu \mathrm{L}$ of $50 \%(\mathrm{v} / \mathrm{v})$ TCA, and then chilled on ice. $500 \mu \mathrm{L}$ of ferrous sulfate-ammonium molybdate reagent 
was added to each sample, and the absorbance at $660 \mathrm{~nm}$ was measured with a spectrophotometer (DU640, Beckman) to determine the amount of released phosphate according to Taussky and Shorr (1953). Protein amount was determined with the protein assay dye reagent (Bio-Rad) using BSA as a standard.

\section{Two-dimensional PAGE and western blotting}

Forty $\mu \mathrm{g}$ from each sample was precipitated with 4 volumes of acetone at $-20{ }^{\circ} \mathrm{C}$ overnight. The precipitate was washed with $80 \%$ acetone, dissolved in $8 \mathrm{M}$ urea, $0.5 \% \mathrm{NP}-40,2 \% \beta-$ mercaptoethanol, $0.8 \%$ Pharmalyte $^{\circledR}$ 3-10 for IEF (Amersham Pharmacia Biotech), and $0.01 \%$ BPB, incubated at $39 \div \mathrm{C}$ for 1 hour, applied onto a dry strip gel $(\mathrm{p} I$ 4-7, Amersham Pharmacia Biotech) equilibrated with $8 \mathrm{M}$ urea, $0.5 \%$ Triton-X100, 10 $\mathrm{mM}$ DTT, $2 \mathrm{mM}$ acetic acid, and $0.01 \mathrm{mg} \cdot \mathrm{mL}-1$ orange $\mathrm{G}$ and subjected to IEF at 22650 V.h using a Multiphor II 2D-Electrophoresis System (Amersham Pharmacia Biotech). The strip was immersed in $6 \mathrm{M}$ urea, $0.05 \mathrm{M}$ Tris- $\mathrm{HCl}(\mathrm{pH} 6.8)$, $30 \%$ glycerol, $1 \%$ SDS, and $16 \mathrm{mM}$ DTT for 10 min, followed by $6 \mathrm{M}$ urea, $0.05 \mathrm{M}$ Tris- $\mathrm{HCl}(\mathrm{pH}$ 6.8 ), $30 \%$ glycerol, $1 \%$ SDS, and $0.01 \%$ BPB for $10 \mathrm{~min}$, both with gentle shaking. The strip was then placed onto a separating slab gel for SDSPAGE, electrophoresed in the second dimension. After electrophoresis, the gels were blotted onto a PVDF membrane (ImmobilonTM Transfer Membranes, Millipore) and probed with the antiapyrase antibody from rat as the primary antibody and biotinylated anti-rat Ig species-specific whole antibody from sheep (Amersham Pharmacia Biotech) as the secondary antibody (Shibata et al., 1999). The binding of the secondary antibody was detected with streptavidin-alkaline phosphatase conjugate (Amersham Pharmacia Biotech) with BCIP and NBT as substrates.

\section{Results and Discussion}

Protein content in dormant seed, and during imbibition and germination.

The protein content in embryos was determined in dry and during imbibition and germination of Alaska pea seeds and results were shown in Figure 1. The Highest levels of protein were initially detected in embryos before imbibition and germination. When pea seeds were imbibed in water, the protein content in embryos was decreased. Decreasing of the embryo's protein was lasts up to 20 hours from imbibition. More over the protein content of the embryo of germinated pea seeds was drastically declined after 20 hours of germination. Bewley (1997) reported that subsequent events, including the mobilization of the major storage reserves, are associated with growth of the seedling. Additionally, all of the cellular and metabolic events that are known to occur before the completion of germination of non dormant seeds also occur in imbibed dormant seeds and the metabolic activities of the latter are frequently only subtly different from those of the former.

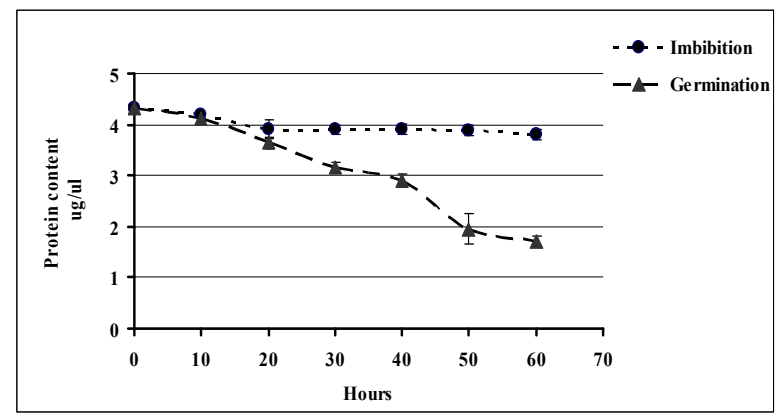

Figure 1. Protein contents of embryonic axes during course of imbibition and germination. Error bars represent $\mathrm{SE} ; \mathrm{n}=5$.

ATPase activity during imbibitions and relationship between seeds imbibition and germination

To study the ATPase activities during imbibition of pea seeds, proteins from whole embryos were extracted after imbibition for 10, 20, $30,40,50$ and 60 hours and assayed against ATP. As can be seen in Figure 3, there was very low ATPase activity in 10 hours imbibed pea seeds and the maximum activity was detected in imbibed embryo after 28 hours but it revert to zero in 60 hours of imbibition. These data indicate that minor ATPase activity associated with early stages of imbibition of pea embryos derived from enzyme other than apyrase (Moustafa et al. 2003), as well as isotypes $46 \mathrm{kDa}$ and $36 \mathrm{kDa}$ seem to be inactive during imbibition. More imbibition time will have a great effect on ATPase activity might be due to absence of aeration and/or due to accumulation of carbon dioxide which released form respiration. The evolved carbon dioxide may cause less 
oxygen content in water. These data in agreement with data obtained previously which indicated that methionine synthase protein was present at low levels in dry mature seeds and the level increased greatly at 24 hours during imbibition, prior to radicle emergence (Gallardo et al., 2002a).

Number of germinated peas seed decreased progressively as the time of imbibitions increased. But 10 hours of imbibitions is quite enough for seed germination, whenever, the germination level decreased with increase the imbibition time more than 10 hours (Figure 2). A minimal growth rate was noted after 60 hours of seed imbibition justifying that more imbibition time affects greatly on the seeds vitality and causes a complete inhibition of germination. It is possible that the relative contribution of nutrition flow from vermiculite to seed embryos would be significant to protein expression, but imbibition has no effect on that aspect.

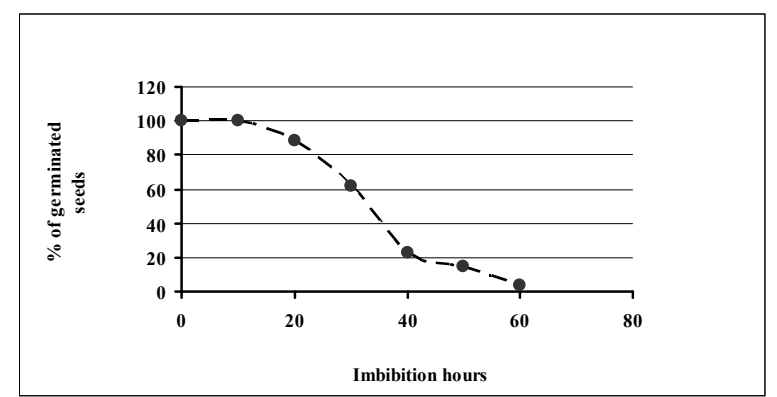

Figure 2. Specific ATPase activity during imbibition course of pea seeds. Homogenates of embryos of dry seeds or imbibed for $10,20,30,40,50$, and 60 hours were assayed against ATP as a substrates, and the data expressed as specific activity (vertical axis: $\mu \mathrm{mol} \cdot \mathrm{min}$ $\left.{ }^{1} \cdot \mathrm{mg}^{-1}\right)$. Error bars represent SE; $\mathrm{n}=5$.

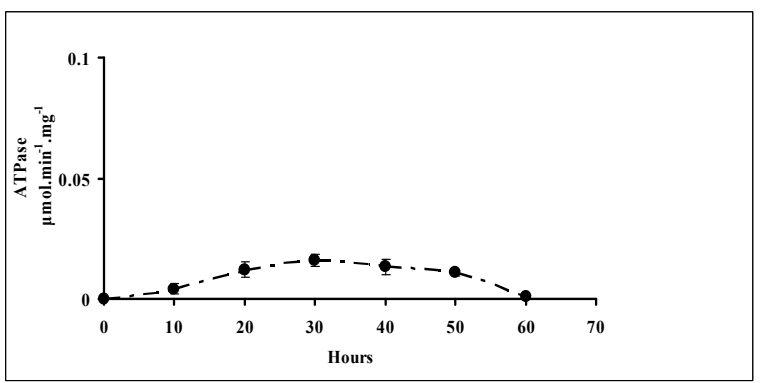

Figure 3. Effects of imbibition hours on pea seeds germination. After $0,10,20,30,40,50,60$ hours of imbibitions, 100 pea seeds were sown in vermiculite to test for the germination.
Status of $46 \mathrm{kDa}$ and $36 \mathrm{kDa}$ isotypes in dormant, imbibed and germinated seeds.

In order to find out if the array of isotypes varies during germination or imbibition, extracted proteins from embryos of dry pea seeds, or imbibed up to 60 hours or germinated up to 24 hours, were subjected to 2D-PAGE to identify their isotypes based on their $\mathrm{p} I$, blotted and probed with an antibody to apyrase (Figure 4). In the 0 hour dry seed and in 60-hours imbibed tissue, 46 $\mathrm{kDa}$ antigenic protein to apyrase furnished thirteen isotypes with $\mathrm{p} I 5.3,5.4,5.6,5.8,6.0,6.3,6.6,6.8$, $7.4,7.5,7.55,7.65$ and 7.7 , and the most abundant the isotypes with $\mathrm{p} I 6.3,7.55$, and 7.65 , and the most predominant one the isotypes with $\mathrm{p} I 7.55$, while $36 \mathrm{kDa}$ furnished only two isotypes with $\mathrm{p} I$ 7.3 and 7.35 .

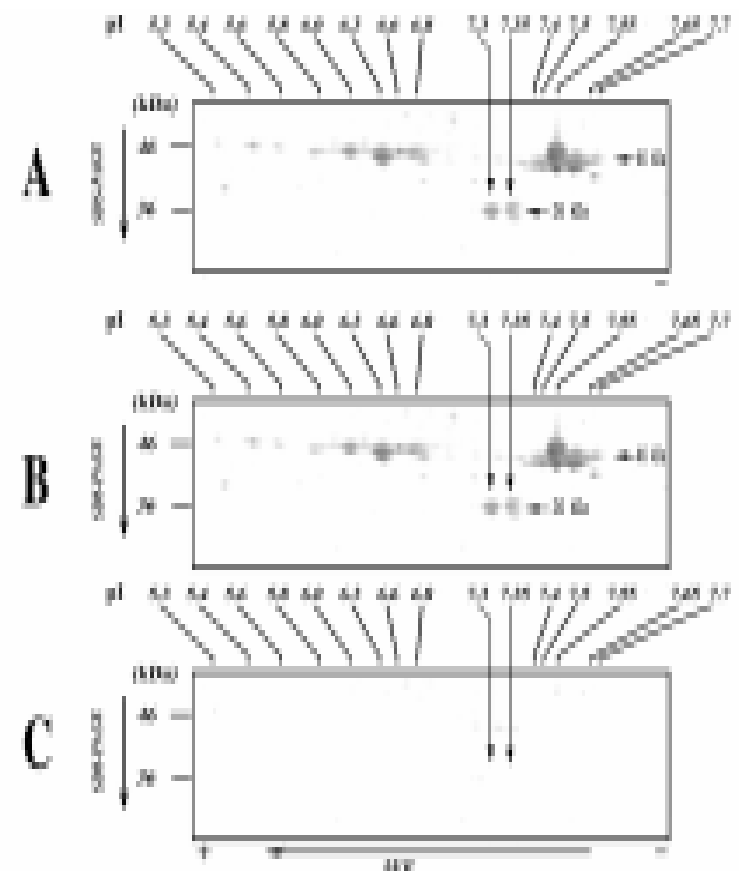

Figure 4. Different isotypes of the immunized 46 and 36 proteins which expressed in embryos of dry pea seeds at different times of imbibition and germination. Proteins from pea embryos were electrophoresed by IEF followed by SDS PAGE, blotted and probed against with anti-apyrase antibody. Panel A; correspond to embryonic axes of dry pea seeds. Panel $\mathrm{B}$; correspond to embryonic axes of 60 hours imbibed pea seeds. Panel C; correspond to embryonic axes of 24 hours of germinated pea seeds. $\mathrm{p} I$ values for $46 \mathrm{kDa}$ $(5.3,5.4,5.6,5.8,6.0,6.3,6.6,6.8,7.4,7.5,7.55,7.65$ and 7.7$)$ and $\mathrm{p} I$ for $36 \mathrm{kDa}(7.3$ and 7.35$)$ are indicated. 
Embryos germinated to 24 hours showed a disappearance of all the isotypes of $46 \mathrm{kDa}$ and 36 $\mathrm{kDa}$. It is reported that the major nucleoside triphosphatase (NTPase) activities in mammalian and pea (Pisum sativum L.) nuclei are associated with enzymes that are very similar both biochemically and immunochemically (Tong et al., 1993).

The western analysis using the antiserum of the $49 \mathrm{kDa}$ gave a positive results with the 13 isotypes of $46 \mathrm{kDa}$ and as well as for the other two belonged to $36 \mathrm{kDa}$, these may be are family genes such the cupin super family of proteins, a stress-induced protein of the slime mould Physarum polycephalum (Castillo et al., 2005). Abe et al., (2002) were succeeded to isolate 5 isotypes of the $49 \mathrm{kDa}$ and named it, P0, P1, P2, P3, and P4, and postulated that these isotypes belong apyrase enzyme and he thought that these forms of the enzymes raised due to phosphoryaltion process of the gene control such enzyme, to enable it to work in different substrate. For such reason we can concluded that the isolated $46 \mathrm{kDa}$ and $36 \mathrm{kDa}$ proteins may be another enzymes which cooperate in ATP hydrolysis and as well as protein hydrolysis essentials for the seed germination. The different isotypes for the two enzymes may not only for phosphoryaltion modification but it is kind of epigenetic which control such genes. Tong et al. (1993), found that monoclonal antibody (MAb) $\mathrm{C} 2$, raised to human lamin $\mathrm{C}$, both immunoprecipitates the major (47 $\mathrm{kDa})$ NTPase in pea nuclei and recognizes it in western blot analyses. A polyclonal antibody preparation raised to the $47-\mathrm{kD}$ pea NTPase (pc480) reacts with the same lamin bands that are recognized by MAb C2 in mammalian nuclei.

We anticipate that those isotypes might be important during the very early stages of germination or involved in various way to break seed dormancy. However, since those isotypes disappeared completely at the earliest stages of germination, this suggests that the initiation of germination and breaking the seed dormancy followed by development of embryonic axes will not be achieved unless consuming them. This result is in good agreement with previous findings, which stated that in addition to the storage proteins, mature dry seeds accumulate during maturation a number of proteins that are involved in various cellular processes such as DNA replication and transcription, translation, metabolism, or defense mechanisms (Bewley and Black 1994; Bradford et al., 2000; Castillo et al., 2005). So that our finding and other recent studies identified these genes considered as for germination requirements, (Bove et al., 2001; Bradford et al., 2000; Koornneef et al., 2002; Potokina et al., 2002; Van der Geest 2002; Duque and Chua 2003; Gallardo et al., 2002a, 2002b; Jabrin et al., 2003; Ogawa et al., 2003).

We suggested that may be the mature seed proteins also play a secondary role as storage proteins, but taking into account their expression pattern (see above), they do not seem typical seed storage proteins, because it is diminish once the seed completely germinated. The expression pattern of the 46 and $36 \mathrm{kDa}$ genes is related to protecting the chromatin against stress injuries. All the above considerations suggested that both of the two proteins a hitherto undescribed role within the apyrase family, namely, to serve as a precursor of two stress-related multifunctional seed proteins, which, among other functions, play a function in nuclear processes.

\section{Conclusion}

In conclusion, both of the 46 and $36 \mathrm{kDa}$ proteins are two separate enzymes correlated to apyrase enzyme. Both of the two enzymes have different isotypes which might be a kind of epigenetic effect. In addition, these genes tend to make post transcription or post translation modification, giving many isotypes each one of them able to perform a specific function during the germination process. These proteins playing important roles to protect the dormanant and germinated seed against the most biotic and abiotic stresses.

\section{References}

Abe S., Moustafa M.F.M., Shibata K., Yoneda M, Davies E. 2002. Purification and characterization of the major isotypes of apyrase from the cytoskeleton fraction in Pisum sativum. Plant Physiology and Biochemistry, 40: 1019-1023.

Bewley J.D. 1997. Seed Germination and Dormancy. Plant Cell, 9: 1055-1066. 
Bewley J.D, Black M. 1994. Seeds. Physiology of Development and Germination. Ed 2. Plenum Press, New York.

Bewley J.D., Burton R.A., Morohashi Y., Fincher G.B. 1997. Molecular cloning of a cDNA encoding a $(1 \rightarrow 4)-\beta$ mannan endohydrolase from the seeds of germinated tomato (Lycopersicon esculentum). Planta, 203: 454-459.

Bradford M.M. 1976. A rapid and sensitive method for the quantitaion of microgram quantities of protein utilizing the principle of protein-dye binding. Anal Biochem, 72: 248-254.

Bradford K.J., Chen F., Cooley M.B., Dahal P., Downie B., Fukunaga K.K., Gee O.H., Gurusinghe S., Mella R.A., Nonogaki H., Wu C-T., Yang H., Yim K-O. 2000. Gene expression prior to radicle emergence in imbibed tomato seeds. In M Black, KJ Bradford, J Vazquez-Ramos, eds, Seed Biology: Advances and Applications. CAB International, Wallingford, UK, 231-251.

Bove J., Jullien M., Grappin P. 2001. Functional genomics in the study of seed germination. Genome Biol, 3: 1002.1-1002.5.

Castillo J., Genovés A., Franco L., Rodrigo M.I. 2005. A multifunctional bicupin serves as precursor for a chromosomal protein of Pisum sativum seeds. Journal of Experimental Botany, 56: 3159-3169.

Chivasa S., Ndimba B.K., Simon W.J., Lindsey K., Slabas A.R. 2005. Extracellular ATP Functions as an Endogenous External Metabolite Regulating Plant Cell Viability. The Plant Cell, 17: 3019-3034.

Day R.B., McAlvin C.B., Loh J.T., Denny R.L., Wood T.C., Young N.D., Stacey G. 2000. Differential expression of two soybean apyrases, one of which is an early nodulin. $\mathrm{Mol}$ Plant-Microbe Interact, 13: 1053-1070.

Duque P., Chua N.H. 2003. IMB1, a bromodomain protein induced during seed imbibition, regulates $\mathrm{ABA}$ - and phyA-mediated responses of germination in Arabidopsis. The Plant journal: for cell and molecular biology, 35: 787-799.

Gallardo K.; Job C.; Groot S.P.C.; Puype M.; Demol H.; Vandekerckhove J.; Job D. 2002a. Importance of methionine biosynthesis for Arabidopsis seed germination and seedling growth. Physiologia Plantarum, 116: 238-247.

Gallardo K.; Job C.; Groot S.P.C.; Puype M.; Demol H.; Vandekerckhove J.; Job D. 2002b. Proteomics of Arabidopsis seed germination: a comparative study of wild-type and gibberellin-deficient seeds. Plant Physiol, 129: 823-837.
Galili G., Altschuler Y., Levanony H. 1993. Assembly and transport of seed storage proteins. Trends Cell Biology, 3: 437-442.

Gubler F., Millar A.A., Jacobsen J.V. 2005. Dormancy release, ABA and pre-harvest sprouting. Current Opinion in Plant Biology, 8: 183-187.

Hsieh H.L., Tong C.G., Thomas C., Roux S.J. 1996. Light-modulated abundance of an mRNA encoding a calmodulin-regulated, chromatinassociated NTPase in pea. Plant Mol. Biol, 30: 135-147.

Jabrin S., Ravanel S., Gambonnet B., Douce R., Rébeillé F. 2003. One-carbon metabolism in plants. Regulation of tetrahydrofolate synthesis during germination and seedling development. Plant Physiology, 131: 1431-1439.

Jenner C.F. 1982. Storage of starch. In Encyclopedia of Plant Physiology (NS): Plant Carbohydrates, F.A. Loewus and W. Tanner, eds (Berlin: Springer-Verlag), 13A: 700-747.

Koornneef M., Bentsink L., Hilhorst H. 2002. Seed dormancy and germination. Current Opinion in Plant Biology, 5: 33-36.

Komoszynski M.A., Wojtczak A. 1996. Apyrases (ATP diphosphohydrolases, EC 3.6.1.5) function and relationship to ATPases. Biochim Biophys Acta, 1310: 233-241.

Ogawa M., Hanada A., Yamauchi Y., Kuwahara A., Kamiya Y, Yamaguchi S. 2003. Gibberellin biosynthesis and response during Arabidopsis seed germination. Plant Cell, 15: 1591-1604.

Plesner L. 1995. Ecto-ATPases: identities and functions. International Review of Cytology, 158: $141-214$

Potokina E., Sreenivasulu N., Altschmied L., Michalek W., Graner A. 2002. Differential gene expression during seed germination in barley (Hordeum vulgare L.). Funct Integr Genomics, 2: 28-39.

Roberts N.J., Brigham J., Wu B., Murphy J.B., Volpin H., Philips D.A., Etxler M.E. 1999. A Nod factor-binding lectin is a member of a distinct class of apyrases that may be unique to the legumes. Mol Gen Genet, 262: 261-267.

Shibata K., Morita Y., Abe S., Stanković B., Davies E. 1999: Apyrase from pea stems: Isolation, purification, characterization and identification of an NTPase from the cytoskeleton fraction of pea stem tissue. Plant Physiology and Biochemistry, 37: 1-8.

Shotwell M.A., Larkins B.A 1989. The molecular biology and biochemistry of seed storage proteins. In The Biochemistry of Plants, A. Marcus, ed (San Diego, CA: Academic Press), 15: 297-345. 
Slack C.R., Browse J.A. 1984. Synthesis of storage lipids in developing seeds. In Seed Physiology, D.R. Murray, ed (Sydney, Australia: Academic Press), 209-244.

Taussky H.H., Shorr E. 1953. A microcolorimetric method for the determination of inorganic phosphate. J Biol Chem, 202: 675-685.

Thomas, S. Y., Naus K., Lloyd A., Roux S. 1999. Apyrase functions in plant phosphate nutrition and mobilizes phosphate from extracellular ATP. Plant Physiology, 119: 543-551.
Tong C.G., Dauwalder M., Clawson G.A., Hatem C.L., Roux S.J 1993. The major nucleoside triphosphatase in pea (Pisum sativum L.) nuclei and in rat liver nuclei share common epitopes also present in nuclear lamins. Plant Physiology, 101: 1005-1011.

Van der Geest A.H. 2002. Seed genomics: germinating opportunities. Seed Sci Res, 12: 145-153. 